Sains Malaysiana 49(7)(2020): 1669-1686

http://dx.doi.org/10.17576/jsm-2020-4907-18

\title{
Organic Extracts of Asian Plants Potentially Support Thrombolysis in Varied BMI Groups
}

(Ekstrak Organik Tumbuhan Asia Berpotensi Menyokong Trombolisis dalam Kumpulan BMI Berbeza)

Md. Imtiazul Kabir, Md. Mominur Rahman, Md. Atiar Rahman*, A.T.M. Mostafa Kamal, Md. Adnan, Reedwan Bin Zafar AuniQ, Md. NaZim Uddin Chy, Md. Mehedi Hasan, Md. Areeful Haque, M. Mosharef Hossain BhuiYan, Dina HajJar, ArWa A. MaKKi \& Walla Alelwani

\section{ABSTRACT}

A number of plant-derived drugs have been prescribed for treating atherothrombotic disorders such as myocardial or cerebral infarction. Therefore, this study investigated the individual and combined antithrombotic effects of six Asian plants on individuals with various BMIs. Venous blood drawn from healthy volunteers was allowed to form clots and treated with six organic fractions of Ophiorrhiza harrisiana Heyne, Haldina cordifolia (Roxb.) Ridsdale, Eclipta alba (L.) Hassk, Syzygium operculatum L., Lantana camara L., and Acanthus ilicifolius Linn. using the clot-lysis method. The weight of the clot before and after treatment provided the percentage of clot lysis. Variations in clot lysis in different BMI groups were assessed. A. ilicifolius induced the most thrombolytic activity, whereas L. camara showed slightly lower thrombolytic activity. The maximum clot-lysis activity was primarily observed in different fractions of O. harrisana, H. cordifolia, E. alba, S. operculatum, and A. ilicifolius. However, chloroform fractions of all plants except $\mathrm{O}$. harrisana and $\mathrm{L}$. camara showed maximum activity in individual plants. O. harrisana, $\mathrm{H}$. cordifolia, E. alba, S. operculatum, L. camara, and A. ilicifolius showed the highest significant $(P<0.5$ and $P<0.001)$ clotlysis activity viz., $46.60 \pm 0.79 \%$ (ethyl acetate), $55.40 \pm 1.023 \%$ (chloroform), $48.86 \pm 1.35 \%$ (CCl), $44.89 \pm 1.76 \%$ (chloroform), $29.17 \pm 1.12 \%$ (ethanol), and $56.318 \pm 1.64 \%$ (chloroform). Obtained results were verified by ligandreceptor interaction through in silico approach. In conclusion, $\mathrm{H}$. cordifolia, E. alba, and A. ilicifolius demonstrated promising thrombolytic effects; therefore, it is recommended that they be studied further for their therapeutic potential.

Keywords: A. ilicifolius; E. alba; H. cordifolia; streptokinase; thrombolysis

\section{ABSTRAK}

Terdapat beberapa jenis ubat yang berasal daripada tumbuhan telah ditetapkan penggunaannya untuk merawat gangguan aterotrombotik seperti infarksi miokardium atau serebrum. Oleh itu, kajian ini mengkaji kesan aterotrombotik daripada enam jenis tumbuhan Asia individu dan gabungan terhadap individu dengan nilai BMIs yang bervariasi. Darah vena yang diambil daripada sukarelawan yang sihat dibenarkan untuk membentuk bekuan darah dan dirawat dengan enam pecahan organik iaitu Ophiorrhiza harrisiana Heyne, Haldina cordifolia (Roxb.) Ridsdale, Eclipta alba (L.) Hassk, Syzygium operculatum L., Lantana camara L. dan Acanthus ilicifolius Linn. dengan menggunakan kaedah lisis bekuan. Berat bekuan sebelum dan selepas rawatan memberi peratusan lisis bekuan. Variasi dalam lisis bekuan dalam kumpulan BMI yang berbeza telah dikaji. Aktiviti trombolitik paling tinggi telah teraruh daripada A. ilicifolius, manakala L. camara menunjukkan aktiviti trombolitik yang sedikit rendah. Aktiviti maksimum lisis bekuan diperhati terutama sekali dalam pecahan yang berbeza daripada $\mathrm{O}$. harrisana, $\mathrm{H}$. cordifolia, E. alba, S. operculatum dan A. ilicifolius. Namun, pecahan kloroform daripada semua tumbuhan selain daripada $\mathrm{O}$. harrisana dan L. camara menunjukkan aktiviti maksimum dalam tumbuhan individu. O. harrisana, H. cordifolia, E. alba, S. operculatum, L. camara dan A. ilicifolius menunjukkan nilai ketara tertinggi $(P<0.5$ dan $P<0.001)$ aktiviti lisis bekuan viz., $46.60 \pm 0.79 \%$ (etil asetat), $55.40 \pm 1.023 \%$ (kloroform), $48.86 \pm 1.35 \%$ (CCl ), $44.89 \pm 1.76 \%$ (kloroform), $29.17 \pm 1.12 \%$ (etanol) dan $56.318 \pm 1.64 \%$ (kloroform). Keputusan yang diperoleh disahkan oleh interaksi ligan-reseptor melalui pendekatan in silico. Kesimpulannya, H. cordifolia, E. alba dan A. ilicifolius menunjukkan kesan trombolitik yang berpotensi: Oleh itu, adalah disarankan ia dikaji dengan lebih lanjut untuk potensi terapeutiknya.

Kata kunci: A. ilicifolius; E. alba; H. cordifolia; streptokinase; trombolisis

\section{INTRODUCTION}

Thrombosis is the blockage of blood vessels by a thrombus can result in different kinds of cardiac arrhythmia, acute myocardial infarction, and stroke, which are considered to be leading causes of mortality. Atrial fibrillation (AF) is the most frequent type of cardiac arrhythmia. Like other 
consequences of thrombosis, $\mathrm{AF}$ is associated with increased morbidity and mortality, possibly due to an increased risk of the development of embolic stroke and heart failure (Braunwald et al. 2001). Apart from surgical interventions to remove or bypass cardiac blockages, thrombolytic agents can be used as a good alternative to dissolve blood clots (Berkovitch et al. 2016). Patients with congestive cardiac failure, atherosclerosis, and oncogenic disorder, along with pregnant women, are more vulnerable to occlusion in abnormal locations (James 2009). Apart from these causative factors, being overweight and obesity also affects this phenomenon. Obesity is a consequence of many risk factors, as it increases energy consumption and reduces physical exercise. This has very recently been considered as a potential threat that influences such pathological occurrences. Non-alcoholic fatty liver disease and cardiovascular diseases have common metabolic risk factors.

Atherosclerosis is also a leading consequence of thrombosis. Prompt antithrombotic treatment following coronary artery thrombosis can minimize myocardial damage (Kumar \& Cannon 2009). Fibrinolytic agents available include urokinase (UK), streptokinase (SK), and antithrombotic agents that comprise tissue plasminogen activators (t-PA). All types of thrombolytic agents have significant drawbacks, including the requirement of large doses for maximum effect, limited fibrin specificity, and hemorrhagic tendency. Therefore, the development of improved recombinant variants of existing drugs or alternative options is necessary (Wu et al. 2001).

As an alternative therapy, the use of plant-based natural products has undergone significant development. Such changes occurred because of the recent resurgence of natural and traditional medicine, which are playing a more pronounced role in human healthcare systems (Emran et al. 2015). Efforts have been made toward developing plant-derived drugs with anti-platelet (Briggs et al. 2001), anticoagulant (Leta et al. 2002), anti-thrombotic, and thrombolytic properties (Rajapakse et al. 2005). Some plants have also been reported for their thrombolytic effects, and some herbal agents have been investigated for use in cardiovascular diseases in many studies (Rahman et al. 2013; Vietti Violi et al. 2014). There may be even more plant sources with superior antithrombotic potential. This research investigated the antithrombotic effect of six native herbal plants on the blood of individuals with various BMIs.

All six plants have been chosen based on their ethnopharmacological and ethnobotanical reviews. Ophiorrhiza harrisiana (Rubiaceae), a perennial herb, has been used for its effects in dysentery, body pain, and chest pain. H. cordifolia, or A cordifolia (Rubiaceae), a flowering plant, has the potential to be used as anticancer (Sangameswaran \& Saluja 2012), hepatoprotective (Agarwal et al. 2006), anti-inflammatory (Kaushik et al. 2009), antiamoebic (Iqbal et al. 2009), antidiabetic
(Chaudhary et al. 2012), and antinociceptive (Jain et al. 2006) treatment. Eclipta alba (L.) Hassk. has been reported for use in hepatoprotective activity, antidiabetic activity, analgesic activity, antimicrobial activity, antimalarial activity, cardiovascular activity, immunomodulatory activity, antiepileptic activity, anticancer activity, and anthelmintic activity owing to its variety of phytoconstituents, which has been proven by several years of scientific research (Neeraja \& Margaret 2012). Syzygium operculatum Roxb. (Myrtaceae) is a medium-sized tree found in the southern hilly regions of Bangladesh and is used as astringent for dysentery, ulcers, and sepsis for dermatophyte disorders; its leaf has glucose-lowering effects (Bhaskar \& Samant 2012). Lantana camara L. (Verbanaceae) is an evergreen strong-smelling shrub that exhibits antiproliferative, antimicrobial, fungicidal, insecticidal, and nematicidal activity (Upadhyay et al. 2001). Acanthus ilicifolius (Acanthaceae) is a mangrove species used in traditional medicine for asthma, diabetes, hepatitis, inflammation, and rheumatoid treatments (Hussain et al. 2010). Its bark, leaves, roots, and stem have been reported to be able to prevent tumor growth and cancer progression (Kumar \& Singh 2014). To the best of our knowledge, no evidence has been recorded on their thrombolytic effects. This research investigated the thrombolytic effects of different organic fractions of the six aforementioned Asian plant species.

\section{MATERIALS AND METHODS}

\section{PLANT COLLECTION AND IDENTIFICATION}

Roots of $O$. harrisana (Rubiaceae, Accession No. 7609CTGUH), H. cordifolia Roxb. Ridsdale (Rubiaceae, Accession No. SBU 1116), E. alba L. Hassk (Asteraceae, Accession No. SBU 2657), S. operculatum L. (Myrtaceae, Accession No. SBU 1006), L. camara L. (Verbenaceae, Accession No. SBU 2782), and A. ilicifolius Linn. (Acanthaceae, Accession No. SBU 987) were collected from different parts of the Chittagong region (including Rangamati, Bhatiari Golf Club, Raojan, Cox's Bazaar, Khagrachori, Buttaly Hills, University of Chittagong campus, and other hill-tract areas of Chittagong, Bangladesh). The plants were identified by Dr. Sheikh Bokhtear Uddin, taxonomist and professor at the Department of Botany, University of Chittagong, Bangladesh. The sample specimens of the identified plants are preserved in the botanical herbarium of the University of Chittagong.

\section{EXTRACT PREPARATION AND SOLVENT-SOLVENT PARTITIONING}

Dried plant powders (50-80 mesh, $600 \mathrm{~g}$ of each) (National Blender C/GS107651, National, Japan) were subjected to extraction in absolute methanol (3 L) for 
14 days at room temperature $\left(23 \pm 0.5^{\circ} \mathrm{C}\right)$. The collected supernatant (cheesecloth and Whatman filter paper No. 1) was evaporated under reduced pressure at $40{ }^{\circ} \mathrm{C}$ using a rotary evaporator (RE200, Bibby Sterling Ltd., UK). The resulting crude extracts were fractionated by solventsolvent partitioning using the Kupchan method (Kupchan et al. 1973). The protocol is summarized as a flow chart in Figure 1S. The physical appearances and quantity of the fractions after partitioning are presented in Table 1. All the fractions were stored at $4{ }^{\circ} \mathrm{C}$ in airtight containers for further analysis.

\section{SAMPLE PREPARATION}

One-hundred mg of each of the extracts was suspended in $10 \mathrm{~mL}$ of distilled water, and the suspension was shaken vigorously in a vortex mixer. The suspension was kept overnight and decanted to remove the soluble supernatant, which was filtered through a $0.22 \mu \mathrm{m}$ syringe filter. One hundred $\mu \mathrm{L}$ of this aqueous preparation was added to the microcentrifuge tubes containing the clots to analyze thrombolytic activity.

\section{CHEMICALS AND REAGENTS}

Five $\mathrm{mL}(5 \mathrm{~mL})$ of sterile distilled water was added to the commercially available lyophilized powder (SK vial, Polamin Werk GmbH, Herdecke, Germany) of $15,00,000$ I.U. and mixed properly. This suspension was used as a stock for thrombolytic assay.

\section{BLOOD SPECIMEN}

Twenty-five $\mathrm{mL}(25 \mathrm{~mL})$ of venous blood was drawn from young (ages between 21 and 27 years) and healthy (BMIs between 16.9 and 29.1) male volunteers $(n=50)$ without a history of oral anticoagulant therapy following a protocol approved by the Ethics Approval Committee of Chittagong Medical College, Bangladesh. An earlier ethics approval, number ME-CMC 2014/05, was taken from Chittagong Medical College for blood collection from volunteers. Blood collection and preservation were conducted by pathologist Dr. Shafiqul Islam (Premium Hospital Pvt. Ltd., Chittagong). $500 \mu \mathrm{L}$ of blood was transferred to each of the eight previously weighed microcentrifuge tubes to form clots.

\section{STATEMENT ON INFORMED CONSENT OF THE DONORS}

The volunteer donors were served a consent form, which informed the title of the research project, name and detail contact of investigators as well as purpose of the research. Research description on a step-by-step brief of the proposed research, inclusion and exclusion criteria of the donors, whether donors received any therapy or not, the volume of blood to be collected, the possible inconvenience of the puncture sites and the time needed for the blood sampling was mentioned. The interpretation was made on if future use of the research data beyond the current study is desired. Donor, whether could withdraw his sample data, was disclosed. The restriction of sample to that individual study and not for future research projects was pointed in the consent form. Potential adverse effect, discomforts, injuries, or inconvenience associated with donors in this study was connected as informed consent statement. If there was known harmful events to the donors, current knowledge on the occurrence of the harm, clinical consequence of the harm; and any relevant knowledge regarding the probability of reversibility and that these discomforts were transient were also added. Confidentiality statement was added in the consent form in the way that 'confidentiality will be respected and no information that discloses the identity of the participant will be released or published without consent unless required by law of states'. Finally, detail contacts of researchers were provided in case of any question of the donors regarding the study. The consent form was concluded with the consent disclosure of donor as Yes/NO followed by donor's signature.

\section{METHOD OF BMI MEASUREMENT}

Body mass index (BMI, $\mathrm{kg} / \mathrm{m}^{2}$ ) was calculated as the weight (in $\mathrm{kg}$ ) divided by the height (in $\mathrm{m}$ ) squared. Trained field staff was appointed to measure the weights and heights using standardized protocols of the World Health Organization (WHO). A calibrated beam scale was used to measure the weight while the participant was barefoot and wore very light clothing (approximately $0.1 \mathrm{~kg}$ ). Height was measured without shoes to the nearest $0.1 \mathrm{~cm}$ using a portable stadiometer. In this study, overweight and obesity were defined according to participants' BMI; BMIs between 24.0 and 27.9 are overweight, and those above 28.0 are obese (Wu 2006). However, according to the definitions of WHO, underweight, normal weight, overweight, and obese are defined as the following BMI ranges: underweight (BMI less than 18.5), normal weight (BMI 18.5 to 24.9), overweight (BMI 25 to 29.9), and obese (BMI 30 or more).

\section{CLOT LYSES}

Experiments for clot lysis were carried as reported previously (Prasad et al. 2006). Briefly, $4 \mathrm{~mL}$ of venous blood was drawn from the healthy volunteers to distribute in eight different pre-weighed sterile microcentrifuge tubes $(0.5 \mathrm{~mL} /$ tube $)$ placed for incubation at $37{ }^{\circ} \mathrm{C}$ for $45 \mathrm{~min}$. After clot formation, serum was completely removed without disturbing the clot and each tube having clot was again weighed to determine the clot weight (clot weight $=$ weight of clot containing tube - the weight of tube alone). To each microcentrifuge tube containing preweighed clot, $100 \mu \mathrm{L}$ of different organic extracts of the five plants (O. harrisana, H. cordifolia, E. alba, S. operculatum, L. camara, and A. ilicifolius) were added separately. A 100 
$\mu \mathrm{L}$ of SK (positive control) and similar volume of distilled water (negative non-thrombolytic control) were separately added to the control tubes numbered. All the tubes were incubated at $37{ }^{\circ} \mathrm{C}$ for $90 \mathrm{~min}$ and observed for clot lysis. After incubation, released fluids were removed and tubes were reweighed to observe the difference in weight before and after clot disruption. The observed difference was expressed as a percentage of clot lysis. The experiment was repeated thrice with the blood samples of the fifty healthy volunteers.

\section{STATISTICAL ANALYSIS}

All data are presented as a mean \pm SD. The significance between \% clot lysis by SK and plant extracts was tested by the paired t-test analysis using the software SPSS, version 22.0 (SPSS for Windows, Version 18.0, IBM Corporation, New York, USA). The mean differences between positive and negative control were considered as significant at $P$ values $<0.5$ and 0.001 . Figures have been constructed using GraphPad Prism 6.

\section{DOCKING ANALYSIS}

\section{PROTEIN PREPARATION}

Three dimensional crystal structure of Tissue Plasminogen Activator (PDB id: 1A5H) was downloaded in pdb format from the protein data bank (Berman et al. 2000). After that, structure was prepared and refined using the Protein Preparation Wizard of Schrödinger-Maestro v10.1. Charges and bond orders were assigned, hydrogens were added to the heavy atoms, selenomethionines were converted to methionines, and all waters were deleted. Using force field OPLS_2005, minimization was carried out setting maximum heavy atom RMSD (root-meansquare-deviation) to $0.30 \AA$.

\section{LIGAND PREPARATION}

Compounds were retrieved from Pubchem databases, i.e. g-cadinene (CID 92313), b-farnesene (CID 5281517), 7-hydroxycoumarin (CID 5281426), apigenin (CID 5280443), b-caryophyllene (CID 5281515) and spathulenol (CID 522266). The 3D structures for these were built by using Ligprep2.5 in Schrödinger Suite 2015 with an OPLS_2005 force field. Their ionization states were generated at $\mathrm{pH} 7.0 \pm 2.0$ using Epik2.2 in Schrödinger Suite. Up to 32 possible stereoisomers per ligand were retained.

\section{RECEPTOR GRID GENERATION}

Receptor grids were calculated for prepared proteins such that various ligand poses bind within the predicted active site during docking. In Glide, grids were generated keeping the default parameters of van der Waals scaling factor 1.00 and charge cutoff 0.25 subjected to OPLS 2005 force field. A cubic box of specific dimensions centered on the centroid of the active site residues (Reference ligand active site) was generated for receptor. The bounding box was set to $14 \AA \times 14 \AA \times 14 \AA$ for docking experiments.

\section{GLIDE STANDARD PRECISION (SP) LIGAND DOCKING}

SP flexible ligand docking was carried out in Glide of Schrödinger-Maestro v 10.1 (Friesner et al. 2006, 2004) within which penalties were applied to non-cis/ trans amide bonds. Van der Waals scaling factor and partial charge cutoff was selected to be 0.80 and 0.15 , respectively, for ligand atoms. Final scoring was performed on energy-minimized poses and displayed as Glide score. The best docked pose with lowest Glide score value was recorded for each ligand.

\section{RESULTS AND DISCUSSION}

The addition of $100 \mu \mathrm{L}$ SK to the clots showed 86.16 $\pm 1.02 \%$ clot lysis. Sterile distilled water-treated clots showed very negligible clot lysis $(5.69 \pm 3.09 \%)$. The mean differences in clot-lysis percentages of positive and negative controls were significant (for both, $P$ values are $<0.001)$. Chloroform fractions of $A$. illicifolious showed the highest $(56.31 \pm 1.64 \%)$ significant $(P$ values $<0.05)$ clot-lysis activity among all extracts. Ethyl acetate (49.23 $\pm 2.31 \%$ ), pet ether $(48.13 \pm 2.41 \%), \mathrm{CCl}_{4}(53.91 \pm 2.04 \%)$, and ethanol $(49.15 \pm 2.55 \%)$ fractions of $A$. illicifolius, as along with petroleum ether $(48.73 \pm 1.57 \%)$ and methanol $(47.86 \pm 2.60 \%)$ fractions of E. alba, demonstrated significant $(P$ values $<0.001)$ clot lysis, close enough in value to that of $A$. ilicifolius chloroform fractions. An exception is the chloroform fraction of $H$. cordifolia, having a clot-lysis capacity of $55.40 \pm 1.02 \%$ (with the low significance of $P<0.5$ ). There were some more fractions of $O$. harrisana, H. cordifolia, E. alba, and A. ilicifolious that showed considerable clot lysis, but a moderate significance level. These are ethyl acetate fraction $(46.60 \pm 0.79 \%)$ of $O$. harrisana; methanol fraction $(47.81 \pm 0.89 \%)$ of H. cordifolia; and ethanol (48.56 $\pm 1.76 \%), \mathrm{CCl}_{4}(48.86$ $\pm 1.35 \%)$, and chloroform $(48.11 \pm 1.29 \%)$ fractions of E. alba, which has moderate significance levels ( $P$ value ranging from $<0.5$ to $<0.01)$. Methanol $(38.45 \pm 0.80 \%)$ and ethanol $(41.36 \pm 0.82 \%)$ fractions of $O$. harrisana, $\mathrm{CCl}_{4}$ $(38.16 \pm 0.87 \%)$ and pet ether $(39.95 \pm 0.80 \%)$ fractions of $H$. cordifolia, the ethyl acetate $(44.85 \pm 2.26 \%)$ fraction of E. alba, and chloroform (44.89 $\pm 1.76 \%)$ and ethyl acetate $(39.75 \pm 1.80 \%)$ fractions of $S$. operculatum, had moderately significant clot-lysis capacity $(P$ values $<0.05$ to $<0.001$ ) with the positive control. The rest of the fractions showed much lower clot lysis-statistically insignificant to the positive control. The percentage of clot lysis measured for different organic extracts and appropriate controls are shown in Table 2 and 3 and Figures 1 to 3 . The variations in thrombolytic activities of different extracts for volunteers with different BMIs are shown in Tables 4 to 6 . We found 
the percentile of clot lysis in moderate-BMI individuals, on average, is higher than that of the other two classes.

A grid-based docking model was used to analyze the binding pattern of molecules with the amino acids present in the active pocket of the protein (Figure 4). The prepared protein tissue plasminogen activator (PDB id: $1 \mathrm{~A} 5 \mathrm{H}$ ) was made to interact with Gamma-cadinene, $\beta$-farnesene, 7-hydroxycoumarin, apigenin, $\beta$-caryophyllene, and spathulenol isolated from experimental plants. Depending on the D-score and gliding energy, the best scores (-6.331) were chosen for molecular-docking analysis (Table 7), and their respective graphs are illustrated based on site points and hydrophobicity (yellow), hydrogen-bond donors (blue), and hydrogen-bond acceptors (red) (Figure 4). The data showed that apigenin has the lowest binding energy and free energy, indicating the strongest ability for bond formation, while 7-hydroxycoumarin and spathulenol followed next.

Most major thrombolytic drugs work by activating the enzyme plasminogen, which removes the cross-linked fibrin mesh. This makes the clots soluble and proceeds to further proteolysis through other enzymes, restoring blood circulation over the susceptible location of thrombosis. Thus, antithrombotic agents are effective for the treatment of myocardial infarction, thromboembolic strokes, and deep-vein thrombosis, clearing blocked arteries and avoiding permanent damage to the perfused tissue (Ali et al. 2013). A number of prescribed drugs approved by the FDA presently have originated from plant-based sources. A variety of plant sources, particularly fruits and vegetables, have been studied for their supplements having antiplatelet, anticoagulant, and fibrinolytic properties. Consumption of such foods can result in mitigating coronary issues and stroke (Torres-Urrutia et al. 2011).

In this research, six different extracts of six types of plants exhibited antithrombotic activity, among which the crude extracts and fractions of A. ilicifolius induce increased thrombolytic activity. L. camara demonstrates slightly lower thrombolytic activity. The maximum clotlysis activity was observed in different fractions of $O$. harrisana, H. cordifolia, E. alba, S. operculatu, and $A$. ilicifolius. However, chloroform fractions of all plants except $O$. harrisana and $L$. camara showed maximum activity in individual plants. This means that chloroformsoluble compounds are considerable to be responsible for thrombolytic activity. Methanol fractions follow chloroform closely in terms of clot-lysis ability. For $O$. harrisana and L. camara, methanol and ethanol extracts showed maximal activity. It is evident that there are bacterial contaminants in plants that have plasminogen receptors that bind plasminogen (Emran et al. 2015).

However, BMI-dependent analysis of these extracts' thrombolytic potentials shows a common trend of fluctuation along with three distributions of BMI. In most extracts, the blood specimens with a middle range of BMI are at a clear advantage of receiving better thrombolytic effects, other than methanol and ethanol organic fractions of $O$. harrisiana. In contrast, the blood specimens of volunteers with either high or low BMIs receive less antithrombotic effects, perhaps owing to certain biochemical or electrophysiological variations in their blood samples. Nevertheless, the outcomes of this study could show the advantages of these locally famous plants and lead to new findings in the field of antithrombotic research.

Cell-surface bound plasminogen is easily activated to plasmin, which could lead to thrombolysis (Verstraete 2000). The antithrombotic potentials of various plants are shown according to the ingredients of certain thrombolytic proteases enzymes. Staphylokinase and streptokinase, the plasminogen activators of bacteria, act as cofactor compounds that play a vital role in exosite formation and elevate substrate presentation to the enzyme. Staphylokinase activates plasminogen to dissolve thrombi, also destroying the extra-cellular matrix and fibrin fibers that tie cells together (Parry et al. 2000). The bioactive principles of the studied plants can help explore the observed thrombolytic effects in-depth, which could establish the plants as potential therapeutic sources.

Molecular-docking analysis is a way to predict the ligand-receptor interaction for drug-discovery initiatives. Therefore, the in-silico interaction among six prospective compounds and the receptor protein, the plasminogen activator, is required to ascertain the best compound for a given target protein. In contrast to the in vitro analysis, the molecular-docking analysis showed a hydrogen-bonding interaction with major residues in the active site, suggesting a competitive type of inhibition. This difference could be attributed to the subtle difference that exists between the molecular architecture of the tissue plasminogen activator obtained from the protein databank. However, molecular docking faces several challenges, such as developing scoring functions to estimate the free energies of protein-ligand binding. Among all tested compounds, apigenin from Eclipta alba gives the lowest docking score, followed by 7-hydroxycoumarin from Haldina cordifolia and sphathulenol from Lantana camara. It is evident that the negative and low binding energy demonstrates strong bonding. Additionally, apigenin is the potential compound for use, as it inhibits platelet adhesion and thrombus formation (Navarro-Núñez et al. 2008). Furthermore, the performance of molecular docking-which was used to determine the clot-lysis activity of the isolated compounds with serotonin receptors-showed that apigenin displayed a negative and low value (-6.331) of free energy of binding, demonstrating a strong favorable bond. The docking score suggests that apigenin could be the responsible compound for potential clot-lysis activity. 
TABLE 1. Yield variations of different crude extracts at solvent extraction

\begin{tabular}{lcccc}
\hline \multicolumn{1}{r}{ Plant name } & Plant part & Powder taken $(\mathrm{g})$ & Crude obtained $(\mathrm{g})$ & Yield\% $(\mathrm{w} / \mathrm{w})$ \\
\hline O. harrisana & Roots & 600 & 15.39 & 2.56 \\
H. cordifolia & Roots & 600 & 7.92 & 1.32 \\
E. alba & Roots & 600 & 21.44 & 3.57 \\
S. operculatum & Roots & 600 & 17.47 & 2.91 \\
L. camara & Roots & 600 & 11.25 & 1.87 \\
A. ilicifolius & Roots & 600 & 9.38 & 1.56 \\
\hline
\end{tabular}

TABLE 2. Six different fractions of O. harrisana, H. cordifolia, E. alba, S. operculatum, L. camara, and A. ilicifolius obtained after Kupchan-partitioning of the crude extract

\begin{tabular}{|c|c|c|c|c|}
\hline Plant name & Fraction & $\begin{array}{c}\text { Wt. of } \\
\text { fraction }(\mathrm{g})\end{array}$ & $\begin{array}{l}\text { Percentage of } \\
\text { recovery }(\mathrm{W} / \mathrm{W})\end{array}$ & Appearance \\
\hline \multirow[t]{6}{*}{ O. harrisiana } & Methanol & 15.39 & 2.565 & Sticky Blackish green \\
\hline & Ethanol & 0.531 & 0.088 & Sticky \& oily blackish green \\
\hline & $\mathrm{CCl}_{4}$ & 0.29 & 0.048 & Green muddy structure \\
\hline & Petroleum ether & 1.05 & 0.175 & Dark black oily mass \\
\hline & Chloroform & 0.915 & 0.152 & Dark green mass \\
\hline & Ethyl acetate & 0.328 & 0.054 & Little reddish black sticky mass \\
\hline \multirow[t]{6}{*}{ H. cordifolia } & Methanol & 7.92 & 1.32 & Thick tar like structure \\
\hline & Ethanol & 0.19 & 0.031 & Dark brown mass \\
\hline & $\mathrm{CCl}_{4}$ & 0.285 & 0.047 & Brownish ash like mass \\
\hline & Petroleum ether & 0.773 & 0.129 & Thick and sticky black mass \\
\hline & Chloroform & 0.328 & 0.054 & Deep black thick mass \\
\hline & Ethyl acetate & 0.574 & 0.095 & Black-brown oily heavy mass \\
\hline \multirow[t]{6}{*}{ E. alba } & Methanol & 21.44 & 3.573 & Thick black mud like mass \\
\hline & Ethanol & 0.95 & 0.158 & Thick black heavy mass \\
\hline & $\mathrm{CCl}_{4}$ & 0.217 & 0.036 & Thick black mud like mass \\
\hline & Petroleum ether & 0.116 & 0.019 & Sticky and oily mass \\
\hline & Chloroform & 0.798 & 0.133 & Thick black oily mass \\
\hline & Ethyl acetate & 1.274 & 0.212 & Greenish black mass \\
\hline
\end{tabular}




\begin{tabular}{|c|c|c|c|c|}
\hline \multirow[t]{6}{*}{ S. operculatum } & Methanol & 17.47 & 2.911 & Black sticky mass \\
\hline & Ethanol & 1.073 & 0.179 & Black sticky mass \\
\hline & $\mathrm{CCl}_{4}$ & 0.864 & 0.144 & Greenish black oily mass \\
\hline & Petroleum ether & 0.519 & 0.086 & Sticky dark green mud like mass \\
\hline & Chloroform & 0.726 & 0.121 & Black sticky mass \\
\hline & Ethyl acetate & 0.339 & 0.056 & Black sticky mass \\
\hline \multirow[t]{6}{*}{ L. camara } & Methanol & 11.25 & 1.875 & Pitch black muddy structure \\
\hline & Ethanol & 0.223 & 0.037 & Dark \& thick mass \\
\hline & $\mathrm{CCl}_{4}$ & 0.781 & 0.131 & Dark \& thick mass \\
\hline & Petroleum ether & 0.806 & 0.134 & Black sticky mass \\
\hline & Chloroform & 0.291 & 0.048 & Black oily heavy phase \\
\hline & Ethyl acetate & 0.699 & 0.116 & Blackish oily mass \\
\hline \multirow[t]{6}{*}{ A. ilicifolius } & Methanol & 9.38 & 1.563 & Black sticky mass \\
\hline & Ethanol & 0.189 & 0.031 & Black sticky mass \\
\hline & $\mathrm{CCl}_{4}$ & 0.775 & 0.129 & Dark \& thick mass \\
\hline & Petroleum ether & 0.924 & 0.154 & Black sticky mass \\
\hline & Chloroform & 0.479 & 0.079 & Black oily mass \\
\hline & Ethyl acetate & 0.996 & 0.166 & Black sticky mass \\
\hline
\end{tabular}

TABLE 3. Effect of herbal extracts and their different fractions on in vitro clot lysis

\begin{tabular}{|c|c|c|c|c|}
\hline Treatment & Extract or Fraction & $\begin{array}{l}\% \text { of clot lysis } \\
(\text { Mean } \pm \text { SEM })\end{array}$ & $\mathrm{P}$ value & $\begin{array}{l}\text { Level of } \\
\text { Significance }\end{array}$ \\
\hline Water & & $4.15 \pm 0.13$ & $<0.001$ & $* * *$ \\
\hline Streptokinase & & $86.16 \pm 1.02$ & $<0.001$ & $* * *$ \\
\hline \multirow[t]{5}{*}{ O. harrisiana } & Methanol & $38.45 \pm 0.80$ & $<0.5$ & \\
\hline & Ethanol & $43.08 \pm 1.02 *$ & $<0.5$ & \\
\hline & $\mathrm{CCl}_{4}$ & $26.16 \pm 0.78$ & $<1$ & \\
\hline & Petroleum ether & $35.48 \pm 0.78$ & $<1$ & \\
\hline & $\mathrm{CHCl}_{3}$ & $23.21 \pm 0.76$ & $<0.5$ & \\
\hline
\end{tabular}




\begin{tabular}{|c|c|c|c|c|}
\hline & Ethyl acetate & $46.60 \pm 0.79$ & $<1$ & \\
\hline \multirow[t]{6}{*}{ H. cordifolia } & Methanol & $47.81 \pm 0.89$ & $<1$ & \\
\hline & Ethanol & $41.36 \pm 0.82$ & $<1$ & \\
\hline & $\mathrm{CCl}_{4}$ & $38.16 \pm 0.87$ & $<1$ & \\
\hline & Petroleum ether & $39.95 \pm 0.80$ & $<1$ & \\
\hline & $\mathrm{CHCl}_{3}$ & $55.40 \pm 1.02$ & $<0.5$ & \\
\hline & Ethyl acetate & $34.02 \pm 1.66$ & $<0.001$ & $* * *$ \\
\hline \multirow[t]{6}{*}{ E. alba } & Methanol & $47.86 \pm 2.60$ & $<0.001$ & $* * *$ \\
\hline & Ethanol & $48.56 \pm 1.76$ & $<0.005$ & $* *$ \\
\hline & $\mathrm{CCl}_{4}$ & $48.86 \pm 1.35$ & $<0.05$ & $*$ \\
\hline & Petroleum ether & $48.73 \pm 1.57$ & $<0.001$ & $* * *$ \\
\hline & $\mathrm{CHCl}_{3}$ & $48.11 \pm 1.29$ & $<0.05$ & $*$ \\
\hline & Ethyl acetate & $44.85 \pm 2.26$ & $<0.001$ & $* * *$ \\
\hline \multirow[t]{6}{*}{ S. operculatum } & Methanol & $36.97 \pm 1.15$ & $<0.5$ & \\
\hline & Ethanol & $37.53 \pm 2.15$ & $<0.001$ & $* * *$ \\
\hline & $\mathrm{CCl}_{4}$ & $33.47 \pm 1.13$ & $<0.5$ & \\
\hline & Petroleum ether & $35.27 \pm 2.16$ & $<0.001$ & $* * *$ \\
\hline & $\mathrm{CHCl}_{3}$ & $44.89 \pm 1.76$ & $<0.001$ & $* * *$ \\
\hline & Ethyl acetate & $39.75 \pm 1.80$ & $<0.001$ & $* * *$ \\
\hline \multirow[t]{6}{*}{ L. camara } & Methanol & $26.09 \pm 1.00$ & $<1$ & \\
\hline & Ethanol & $29.17 \pm 1.12$ & $<0.5$ & \\
\hline & $\mathrm{CCl}_{4}$ & $28.63 \pm 1.21$ & $<0.5$ & \\
\hline & Petroleum ether & $27.89 \pm 1.45$ & $<0.05$ & $*$ \\
\hline & $\mathrm{CHCl}_{3}$ & $25.95 \pm 1.84$ & $<0.05$ & $*$ \\
\hline & Ethyl acetate & $22.49 \pm 0.89$ & $<1$ & \\
\hline \multirow[t]{6}{*}{ A. ilicifolius } & Methanol & $50.07 \pm 1.83$ & $<0.01$ & $* *$ \\
\hline & Ethanol & $49.15 \pm 2.55$ & $<0.001$ & $* * *$ \\
\hline & $\mathrm{CCl}_{4}$ & $53.91 \pm 2.04$ & $<0.001$ & $* * *$ \\
\hline & Petroleum ether & $48.13 \pm 2.41$ & $<0.001$ & $* * *$ \\
\hline & $\mathrm{CHCl}_{3}$ & $56.31 \pm 1.64$ & $<0.05$ & $*$ \\
\hline & Ethyl acetate & $49.23 \pm 2.31$ & $<0.001$ & $* * *$ \\
\hline
\end{tabular}


TABLE 4. Effect of herbal extracts and their different fractions on in vitro clot lysis and its variation for low BMI holding hosts

Extent of thrombolysis by the extracts for volunteers with low BMI $(\mathrm{BMI}<18.5)$

\begin{tabular}{|c|c|c|c|c|}
\hline Name of plant & Solvent of extract & $\begin{array}{c}\% \text { of thrombolysis } \\
(\text { mean } \pm \text { SEM })\end{array}$ & Significance value & $\begin{array}{c}\text { Significance } \\
\text { level }\end{array}$ \\
\hline Control & & $4.336 \pm 0.4990$ & $<0.01$ & $* *$ \\
\hline Standard & & $86.049 \pm 2.1139$ & $<0.01$ & $* *$ \\
\hline \multirow[t]{6}{*}{ O. harrisiana } & Methanol & $38.897 \pm 1.4463$ & $<0.5$ & \\
\hline & Ethanol & $40.487 \pm 2.0153$ & $<1$ & \\
\hline & $\mathrm{CCl}_{4}$ & $24.355 \pm 1.6107$ & $<0.5$ & \\
\hline & Pet ether & $33.696 \pm 1.6107$ & $<0.5$ & \\
\hline & Chloroform & $21.320 \pm 1.6107$ & $<0.5$ & \\
\hline & EtOAc & $48.056 \pm 1.2949$ & $<0.5$ & \\
\hline \multirow[t]{6}{*}{ H. cordifolia } & Methanol & $45.711 \pm 1.7048$ & $<0.5$ & \\
\hline & Ethanol & $39.246 \pm 1.5252$ & $<0.5$ & \\
\hline & $\mathrm{CCl}_{4}$ & $36.165 \pm 1.8464$ & $<1$ & \\
\hline & Pet ether & $38.053 \pm 1.6487$ & $<0.5$ & \\
\hline & Chloroform & $53.798 \pm 2.2079$ & $<1$ & \\
\hline & EtOAc & $30.020 \pm 3.2287$ & $<0.05$ & $*$ \\
\hline \multirow[t]{6}{*}{ E. alba } & Methanol & $43.904 \pm 4.5961$ & $<0.01$ & $* *$ \\
\hline & Ethanol & $47.261 \pm 2.2467$ & $<1$ & \\
\hline & $\mathrm{CCl}_{4}$ & $44.047 \pm 2.7939$ & $<0.5$ & \\
\hline & Pet ether & $45.761 \pm 3.1015$ & $<0.05$ & $*$ \\
\hline & Chloroform & $44.690 \pm 2.6373$ & $<0.5$ & \\
\hline & EtOAc & $41.118 \pm 4.5170$ & $<0.001$ & $* * *$ \\
\hline \multirow[t]{6}{*}{ S. operculatum } & Methanol & $36.047 \pm 1.8690$ & $<1$ & \\
\hline & Ethanol & $35.547 \pm 3.7445$ & $<0.1$ & \\
\hline & $\mathrm{CCl}_{4}$ & $30.690 \pm 1.9788$ & $<1$ & \\
\hline & Pet ether & $31.832 \pm 4.2219$ & $<0.01$ & $* *$ \\
\hline & Chloroform & $41.047 \pm 2.8739$ & $<0.5$ & \\
\hline & EtOAc & $36.118 \pm 3.6261$ & $<0.05$ & $*$ \\
\hline
\end{tabular}




L. camara
\begin{tabular}{ccc} 
Methanol & $26.190 \pm 2.8521$ & $<1$ \\
Ethanol & $28.261 \pm 2.9558$ & $<1$ \\
$\mathrm{CCl}_{4}$ & $28.690 \pm 2.4079$ & $<1$ \\
Pet ether & $25.404 \pm 3.0153$ & $<0.5$ \\
Chloroform & $24.832 \pm 3.2827$ & $<0.5$ \\
EtOAc & $22.761 \pm 2.9475$ & $<1$ \\
Methanol & $49.404 \pm 2.6738$ & $<1$ \\
Ethanol & $43.832 \pm 3.5565$ & $<0.5$ \\
CCl & & $<9.190 \pm 2.6784$ \\
Pet ether & $41.975 \pm 3.3502$ & $<0.5$ \\
Chloroform & $50.404 \pm 4.0838$ & $<0.1$ \\
EtOAc & $45.475 \pm 4.0606$ & $<*$ \\
\hline
\end{tabular}

TABLE 5. Effect of herbal extracts and their different fractions on in vitro clot lysis and its variation for moderated BMI holding hosts

Extent of thrombolysis by the extracts for volunteers with moderated BMI $(\mathrm{BMI}<19-24)$

\begin{tabular}{|c|c|c|c|c|}
\hline Name of plant & Solvent of extract & $\begin{array}{l}\% \text { of thrombolysis (mean } \pm \\
\text { SEM) }\end{array}$ & Significance value & Significance level \\
\hline Control & & $4.0132 \pm 0.24476$ & $<0.01$ & $* *$ \\
\hline Standard & & $87.8022 \pm 1.93330$ & $<0.01$ & $* *$ \\
\hline \multicolumn{5}{|l|}{ O. harrisiana } \\
\hline & Methanol & $37.4714 \pm 1.62894$ & $<1$ & \\
\hline & Ethanol & $42.9187 \pm 1.63681$ & $<1$ & \\
\hline & $\mathrm{CCl}_{4}$ & $27.1693 \pm 1.51290$ & $<1$ & \\
\hline & Pet ether & $36.5110 \pm 1.51290$ & $<1$ & \\
\hline & Chloroform & $24.2981 \pm 1.36678$ & $<0.5$ & \\
\hline & EtOAc & $48.3692 \pm 1.18686$ & $<0.5$ & \\
\hline
\end{tabular}


H. cordifolia

E. alba

S. operculatum

L. camara

A. ilicifolius
Methanol

Ethanol

$\mathrm{CCl}_{4}$

Pet ether

Chloroform

EtOAc

Methanol

Ethanol

$\mathrm{CCl}_{4}$

Pet ether

Chloroform

EtOAc

Methanol

Ethanol

$\mathrm{CCl}_{4}$

Pet ether

Chloroform

EtOAc

Methanol

Ethanol

$\mathrm{CCl}_{4}$

Pet ether

Chloroform

EtOAc

Methanol

Ethanol

$\mathrm{CCl}_{4}$

Pet ether

Chloroform

EtOAc
$49.7378 \pm 1.70705$

$42.8527 \pm 1.69856$

$39.3593 \pm 1.63600$

$41.3384 \pm 1.52332$

$56.0873 \pm 1.79034$

$38.5530 \pm 3.13580$

$51.8947 \pm 4.90058$

$53.0280 \pm 3.10360$

$53.2947 \pm 2.50841$

$52.7613 \pm 2.80057$

$51.2280 \pm 2.28678$

$50.3613 \pm 4.12674$

$38.8947 \pm 2.20905$

$42.0280 \pm 5.04662$

$36.6280 \pm 2.34086$

$40.9613 \pm 4.11402$

$50.6280 \pm 3.62703$

$43.6947 \pm 3.31452$

$26.3613 \pm 1.51290$

$30.2280 \pm 2.08372$

$31.5613 \pm 2.64393$

$<0.5$

$31.6280 \pm 2.70868$

$<0.5$

$27.6280 \pm 4.42218$

$<0.1$

$30.1613 \pm 4.65595$

$<0.05$

$55.0947 \pm 3.58306$

$<0.05$

$59.0280 \pm 5.23470$

$<0.001$

$61.6280 \pm 3.77324$

$<0.01$

$<0.001$

$56.6280 \pm 4.59040$

$<0.1$

$60.0947 \pm 2.84609$

$<0.01$ 
TABLE 6. Effect of herbal extracts and their different fractions on in vitro clot lyses and its variation for high BMI holding hosts

Extent of thrombolysis by the extracts for volunteers with high BMI (BMI >25)

\begin{tabular}{|c|c|c|c|c|}
\hline Name of drug or plant & Solvent of extract & $\begin{array}{c}\% \text { of thrombolysis } \\
(\text { Mean } \pm \text { SEM })\end{array}$ & Significance value & Significance level \\
\hline Control & & $4.062 \pm .2209$ & $<0.01$ & $* *$ \\
\hline Standard & & $85.089 \pm 1.4661$ & $<0.01$ & $* *$ \\
\hline \multirow[t]{6}{*}{ O. harrisiana } & Methanol & $38.864 \pm 1.2295$ & $<1$ & \\
\hline & Ethanol & $44.928 \pm 1.6121$ & $<0.5$ & \\
\hline & $\mathrm{CCl}_{4}$ & $26.658 \pm 1.1017$ & $<1$ & \\
\hline & Pet ether & $35.955 \pm 1.0937$ & $<1$ & \\
\hline & Chloroform & $23.716 \pm 1.0950$ & $<1$ & \\
\hline & EtOAc & $44.383 \pm 1.3344$ & $<1$ & \\
\hline \multirow[t]{6}{*}{ H. cordifolia } & Methanol & $47.841 \pm 1.3120$ & $<1$ & \\
\hline & Ethanol & $41.724 \pm 1.1427$ & $<1$ & \\
\hline & $\mathrm{CCl}_{4}$ & $38.645 \pm 1.2181$ & $<1$ & \\
\hline & Pet ether & $40.228 \pm 1.1306$ & $<1$ & \\
\hline & Chloroform & $55.988 \pm 1.5081$ & $<0.5$ & \\
\hline & EtOAc & $33.459 \pm 2.3271$ & $<0.01$ & $* *$ \\
\hline \multirow[t]{6}{*}{ E. alba } & Methanol & $47.660 \pm 4.1636$ & $<0.001$ & $* * *$ \\
\hline & Ethanol & $46.279 \pm 3.1814$ & $<0.01$ & $* *$ \\
\hline & $\mathrm{CCl}_{4}$ & $48.946 \pm 1.6302$ & $<0.5$ & \\
\hline & Pet ether & $47.850 \pm 2.3371$ & $<0.05$ & $*$ \\
\hline & Chloroform & $48.184 \pm 1.8410$ & $<0.5$ & \\
\hline & EtOAc & $43.422 \pm 3.2875$ & $<0.001$ & $* * *$ \\
\hline
\end{tabular}


S. operculatum

L. camara

A. ilicifolius

\author{
Methanol \\ $\mathrm{CCl}_{4}$
}

Pet ether

Chloroform

EtOAc

$$
\begin{aligned}
& \text { Methanol } \\
& \text { Ethanol } \\
& \mathrm{CCl}_{4}
\end{aligned}
$$

Pet ether

Chloroform

$$
\text { EtOAc }
$$

Methanol

Ethanol

$\mathrm{CCl}_{4}$

Pet ether

Chloroform

EtOAc
$36.231 \pm 1.9137$

$35.660 \pm 2.6818$

$33.088 \pm 1.5466$

$33.517 \pm 3.0631$

$43.374 \pm 2.5126$

$39.374 \pm 2.6188$

$25.850 \pm 1.1017$

$29.041 \pm 1.1901$

$26.517 \pm 1.4559$

$26.898 \pm 1.9839$

$25.517 \pm 2.2931$

$25.565 \pm 2.5391$

$46.946 \pm 2.9670$

$45.660 \pm 3.7058$

$51.565 \pm 3.3283$

$46.184 \pm 3.8102$

$57.565 \pm 1.6727$

$46.612 \pm 3.5619$
$<0.5$

$<0.01$

$<0.5$

$<0.001$

$<0.01$

$<0.001$

$<1$

$<1$

$<1$

$<0.1$

$<0.5$

$<0.5$

$<0.05$

$<0.01$

$<0.01$

$<0.001$

$<0.5$

$<0.001$

Values are mean \pm SEM for 20 volunteers. Statistical representation of the effective clot lysis percentage by herbal preparations, positive thrombolytic control (Streptokinase) and negative control (sterile distilled water) processed by paired t-test analysis (Dunnett's test). Asterisk $(* P<0.05, * * P<0.01, * * * P<0.001)$ values indicate the level of significance

TABLE 7. Docking scores measured for different compounds isolated from the plants involved in the thrombolytic activity

\begin{tabular}{lcccc}
\hline Compounds name & Docking score & Glide model & Glide energy & Source plant \\
\hline Gamma-cadinene & -4.001 & -23.259 & -18.82 & L. camara \\
$\beta$-farnesene & -0.392 & -22.619 & $\mathrm{j}-26.124$ & L. camara \\
7 -hydroxycoumarin & -5.528 & -34.456 & -24.5 & H. cordifolia \\
Apigenin & -6.331 & -48.647 & -36.414 & E. alba \\
$\beta$-caryophyllene & -3.924 & -22.737 & -18.474 & L. camara \\
Spathulenol & -4.59 & -28.669 & -22.952 & L. camara \\
\hline
\end{tabular}




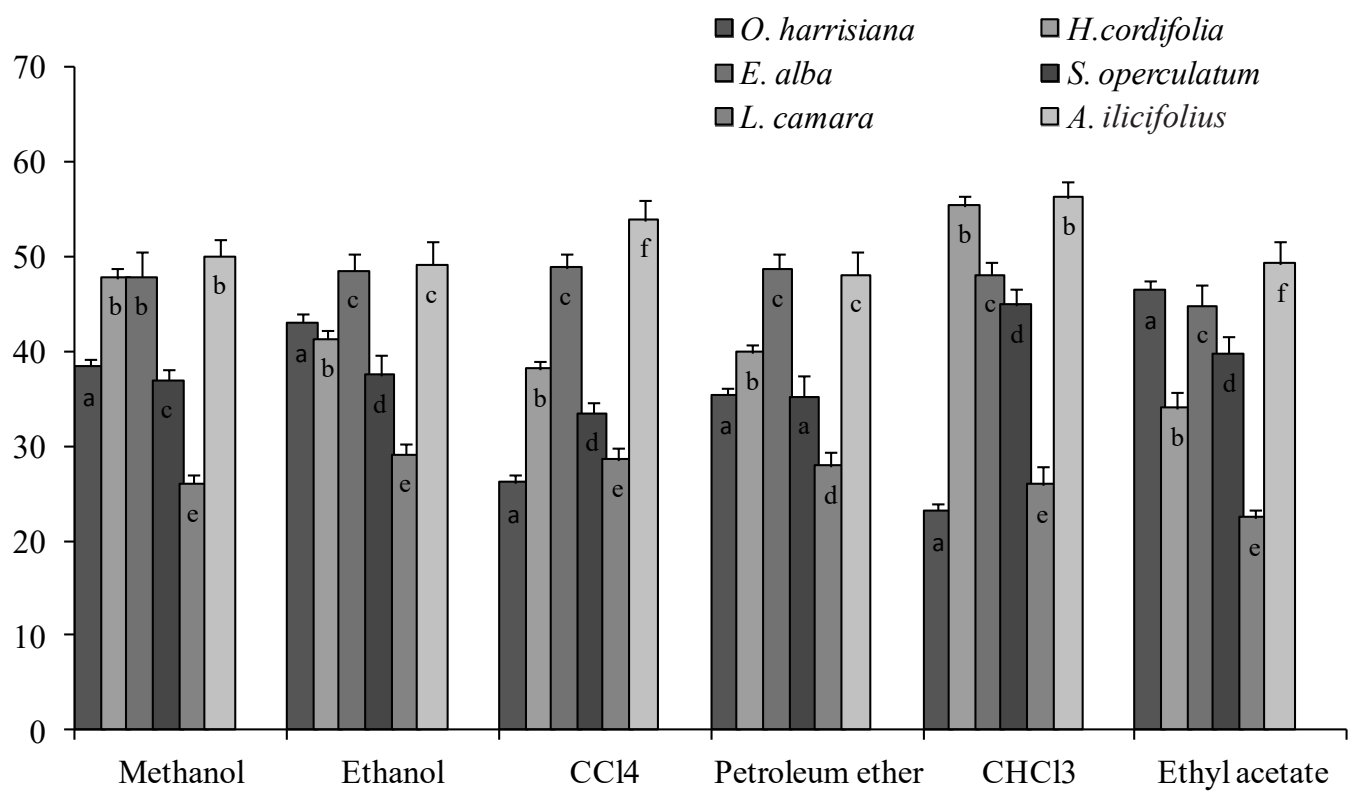

FIGURE 1. Effect of solvents-variation on the extent of clot lysis achieved by six plants. Values are presented as mean \pm SEM for 20 volunteers. Data were processed by paired t-test analysis by using SPSS for windows, version 22.0 followed by Dunnett's test as compared to control (positive and negative). ${ }^{\mathrm{a}-\mathrm{f}}$ superscript letters on inside-end of the line bars are significantly different from each other



FIGURE 2. Average clot lysis effect of individual plant in comparison to both positive and negative control. Values are presented as mean \pm SEM for 20 volunteers. Data were processed by paired t-test analysis by using SPSS for windows, version 22.0, followed by Dunnett's test as compared to control (positive and negative). ${ }^{a-f}$ superscript letters on outside-end of the line bars are significantly different from each other 

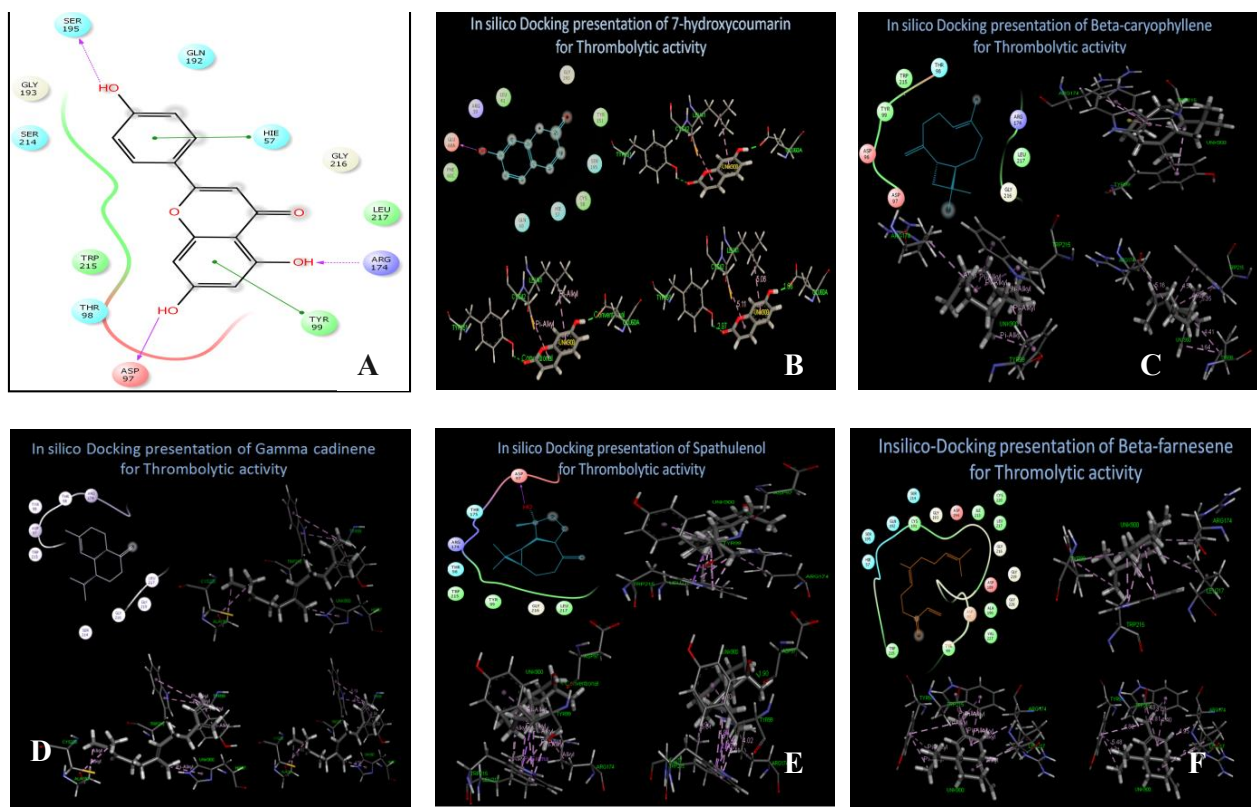

FIGURE 3. Illustrations for the interaction of compounds Gamma-cadinene, $\beta$-farnesene,

7-hydroxycoumarin, apigenin, $\beta$-caryophyllene and spathulenol (A-F) with Tissue plasminogen activator.

Dotted pink-H-bonds to protein side chains, Green - pi-pi stacking interactions, Orange-pi-cation interactions. Ligand atoms that are exposed to solvent are marked with gray spheres. The protein 'pocket' is displayed with a line around the ligand, colored with the color of the nearest protein residue. The gap in the line shows the opening of the pocket

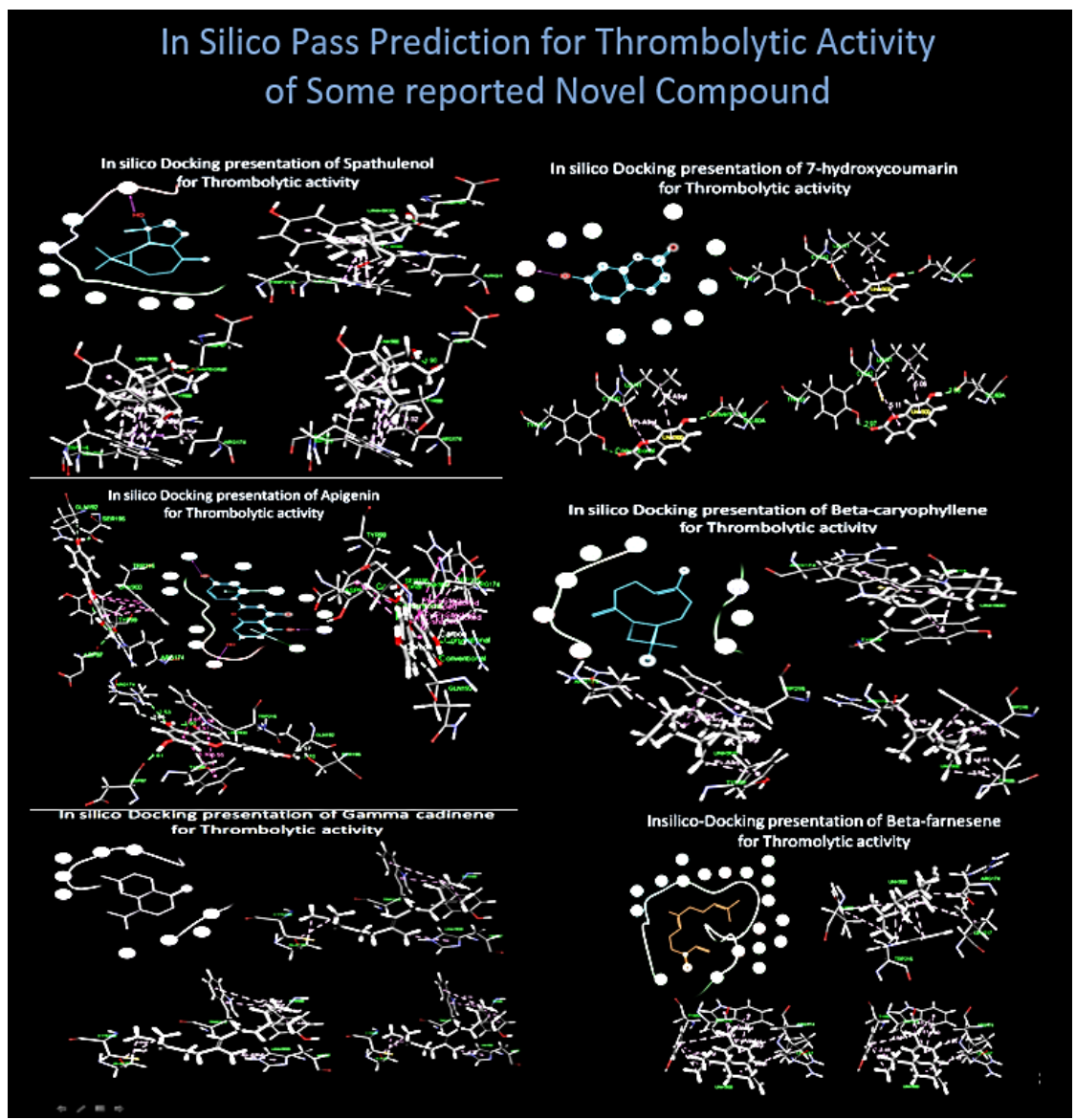

FIGURE 4. Illustrations for in silico pass prediction for compounds Gamma-cadinene, $\beta$-farnesene,

7-hydroxycoumarin, apigenin, $\beta$-caryophyllene and spathulenol (A-F) with tissue plasminogen activator. Dotted pink$\mathrm{H}$-bonds to protein side chains, Green - pi-pi stacking interactions, Orange-pi-cation interactions. Ligand atoms that are exposed to solvent are marked with gray spheres. The protein 'pocket' is displayed with a line around the ligand, colored with the color of the nearest protein residue. The gap in the line shows the opening of the pocket. 


\section{CONCLUSION}

This study attempted to demonstrate the thrombolytic capacity of $O$. harrisana, H. cordifolia, E. alba, S. operculatum, L. camara, and A. ilicifolius, which are considered beneficial in traditional medicine. This was validated in the present work by in vitro blood-clot lysis analysis with their different organic fractions. $H$. cordifolia, E. alba, and A. ilicifolius showed promising thrombolytic effects that warrant further study. Identification of their bioactive components and a dose-response relationship study in an in vivo model can be used to provide an impetus for pharmaceutical preparations. Chloroform-soluble phytochemicals from these plants should be studied, especially focusing on the fractions that could account for the incorporation of a thrombolytic agent to improve the condition of patients suffering from atherothrombotic diseases.

\section{ACKNOWLEDGEMENTS}

All the authors are grateful to Dr. Sheikh Bokhtear Uddin, Professor, Department of Botany, University of Chittagong, Chittagong-4331, Bangladesh for identifying the plant samples. Besides, the authors would like to thank Dr. Shafiqul Islam, Pathologist, Premium Hospital Pvt. Ltd. for the continuous support in this experiment. The authors are also grateful to International Islamic University Chittagong and University of Chittagong for providing facilities to carry out the experiment at the Department of Pharmacy.

\section{REFERENCES}

Agarwal, M., Srivastava, V., Saxena, K. \& Kumar, A. 2006. Hepatoprotective activity of beta vulgaris against $\mathrm{CCl}_{4}$ induced hepatic injury in rats. Fitoterapia 77(2): 91-93.

Ali, M.S., Amin, M.R., Kamal, C.M.I. \& Hossain, M.A. 2013. In vitro antioxidant, cytotoxic, thrombolytic activities and phytochemical evaluation of methanol extract of the Philippense leaves. Asian Pacific Journal of Tropical Biomedicine 3(6): 464-469.

Berkovitch, A., Kivity, S., Klempfner, R., Segev, S., Milwidsky, A., Erez, A., Sabbag, A., Goldenberg, I., Sidi, Y. \& Maor, E. 2016. Body mass index and the risk of new-onset atrial fibrillation in middle-aged adults. American Heart Journal 173: 41-48.

Berman, H.M., Westbrook, J., Feng, Z., Gilliland, G., Bhat, T., Weissig, H., Shindyalov, I.N. \& Bourne, P.E. 2000. The protein data bank. Nucleic Acids Research 28(1): 235-242.

Bhaskar, A. \& Samant, L.R. 2012. Traditional medication of pachamalai hills, Tamilnadu, India. Global Journal of Pharmacology 6(1): 47-51.

Braunwald, E., Kasper, D.L., Hauser, S.L., Longo, D.L., Jameson, J.L. \& Loscalzo, J. 2001. Harrison's Principles of Internal Medicine. New York: McGraw-Hill Education.

Briggs, W.H., Folts, J.D., Osman, H.E. \& Goldman, I.L. 2001. Administration of raw onion inhibits platelet-mediated thrombosis in dogs. The Journal of Nutrition 131(10): 2619-2622.

Chaudhary, P., Goel, B. \& Ghosh, A.K. 2012. Antidiabetic activity of adina cordifolia (roxb) leaves in alloxan induced diabetic rats. Asian Pacific Journal of Tropical Biomedicine 2(3): S1630-S1632.

Emran, T.B., Rahman, M.A., Uddin, M.M.N., Rahman, M.M., Uddin, M.Z., Dash, R. \& Layzu, C. 2015. Effects of organic extracts and their different fractions of five bangladeshi plants on in vitro thrombolysis. BMC Complementary and Alternative Medicine 15(1): 128.

Friesner, R.A., Murphy, R.B., Repasky, M.P., Frye, L.L., Greenwood, J.R., Halgren, T.A., Sanschagrin, P.C. \& Mainz, D.T. 2006. Extra precision glide: Docking and scoring incorporating a model of hydrophobic enclosure for protein-ligand complexes. Journal of Medicinal Chemistry 49(21): 6177-6196.

Friesner, R.A., Banks, J.L., Murphy, R.B., Halgren, T.A., Klicic, J.J., Mainz, D.T., Repasky, M.P., Knoll, E.H., Shelley, M. \& Perry, J.K. 2004. Glide: A new approach for rapid, accurate docking and scoring. 1. Method and assessment of docking accuracy. Journal of Medicinal Chemistry 47(7): 1739-1749.

Hussain, K., Nisar, M.F., Majeed, A., Nawaz, K. \& Bhatti, K.H. 2010. Ethnomedicinal survey for important plants of Jalalpur Jattan, district Gujrat, Punjab, Pakistan. Ethnobotanical Leaflets 14: 807-825.

Iqbal, P.F., Bhat, A.R. \& Azam, A. 2009. Antiamoebic coumarins from the root bark of Adina cordifolia and their new thiosemicarbazone derivatives. European Journal of Medicinal Chemistry 44(5): 2252-2259.

Jain, A.P., Pawar, R.S. \& Singhai, A. 2006. Antiinflammatory and anti-nociceptive activity of adina cordifolia bark. Nigerian Journal of Natural Products and Medicine 10: 204-210.

James, A.H. 2009. Venous thromboembolism in pregnancy. Arteriosclerosis, Thrombosis, and Vascular Biology 29(3): 326-331.

Kaushik, V., Parcha, V. \& Khosa, R.L. 2009. Evaluation of antiinflammatory potential of Haldina cordifolia bark extracts. International Journal of Pharmacy and Pharmaceutical Sciences 20: 126-130.

Kumar, A. \& Cannon, C.P. 2009. Acute coronary syndromes: Diagnosis and management, Part I. Mayo Clinic Proceedings. pp. 917-938.

Kumar, V. \& Singh, P. 2014. Ethnomedicinal plants used as antidote for snake-bite and scorpion-sting in bundelkhand (up), india. IOSR Journal of Environmental Science, Toxicology and Food Technology 8(1): 52-55.

Kupchan, S.M., Tsou, G. \& Sigel, C.W. 1973. Datiscacin, a novel cytotoxic cucurbitacin 20-acetate from Datisca glomerata. The Journal of Organic Chemistry 38(7): 1420-1421.

Leta, G.C., Mourão, P.A. \& Tovar, A.M. 2002. Human venous and arterial glycosaminoglycans have similar affinity for plasma low-density lipoproteins. Biochimica et Biophysica Acta (BBA)-Molecular Basis of Disease 1586(3): 243-253.

Navarro-Núñez, L., Lozano, M., Palomo, M., Martinez, C., Vicente, V., Castillo, J., Benavente-García, O., Diaz-Ricart, M., Escolar, G. \& Rivera, J. 2008. Apigenin inhibits platelet adhesion and thrombus formation and synergizes with aspirin in the suppression of the arachidonic acid pathway. 
Journal of Agricultural and Food Chemistry 56(9): 29702976.

Neeraja, P. \& Margaret, E. 2012. Eclipta alba (1.) hassk: A valuable medicinal herb. International Journal of Current Pharmaceutical Research 2: 188-197.

Parry, M.A., Zhang, X.C. \& Bode, W. 2000. Molecular mechanisms of plasminogen activation: Bacterial cofactors provide clues. Trends in Biochemical Sciences 25(2): 53-59.

Prasad, S., Kashyap, R.S., Deopujari, J.Y., Purohit, H.J., Taori, G.M. \& Daginawala, H.F. 2006. Development of an in vitro model to study clot lysis activity of thrombolytic drugs. Thrombosis Journal 4(1): 14.

Rahman, M.A., Sultana, R., Emran, T.B., Islam, M.S., Rahman, M.A., Chakma, J.S., Rashid, H.U. \& Hasan, C.M.M. 2013. Effects of organic extracts of six Bangladeshi plants on in vitro thrombolysis and cytotoxicity. BMC Complementary and Alternative Medicine 13(1): 25.

Rajapakse, N., Jung, W.K., Mendis, E., Moon, S.H. \& Kim, S.K. 2005. A novel anticoagulant purified from fish protein hydrolysate inhibits factor xiia and platelet aggregation. Life Sciences 76(22): 2607-2619.

Sangameswaran, B. \& Saluja, M. 2012. Anticancer activity of Adina cordifolia against ehrlich ascites carcinoma (eac) in mice. Journal of Pharmacology and Toxicology 5: 7-16.

Torres-Urrutia, C., Guzman, L., Schmeda-Hirschmann, G., Moore-Carrasco, R., Alarcon, M., Astudillo, L., Gutierrez, M., Carrasco, G., Yuri, J.A. \& Aranda, E. 2011. Antiplatelet, anticoagulant, and fibrinolytic activity in vitro of extracts from selected fruits and vegetables. Blood Coagulation \& Fibrinolysis 22(3): 197-205.

Upadhyay, R., Pandey, M., Jha, R. \& Pandey, V. 2001. Eclalbatin, a triterpene saponin from Eclipta alba. Journal of Asian Natural Products Research 3(3): 213-217.

Verstraete, M. 2000. Third-generation thrombolytic drugs. The American Journal of Medicine 109(1): 52-58.

Vietti Violi, N., Fournier, N., Duran, R., Schmidt, S., Bize, P., Guiu, B. \& Denys, A. 2014. Acute mesenteric vein thrombosis: Factors associated with evolution to chronic mesenteric vein thrombosis. American Journal of Roentgenology 203(1): 54-61.

Wu, Y. 2006. Overweight and obesity in China. https://www. ncbi.nlm.nih.gov/pmc/articles/PMC1550451/.

Wu, D.H., Shi, G.Y., Chuang, W.J., Hsu, J.M., Young, K.C., Chang, C.W. \& Wu, H.L. 2001. Coiled coil region of streptokinase $\gamma$-domain is essential for plasminogen activation. Journal of Biological Chemistry 276(18): 15025-15033.

Md. Imtiazul Kabir

Department of Pharmaceutical Science

South Dakota State University

Brookings, 57007

United States of America
Md. Imtiazul Kabir, Md. Mominur Rahman, A.T.M. Mostafa Kamal, Md. Adnan, Reedwan Bin Zafar

Auniq, Md. Nazim Uddin Chy, Md. Mehedi Hasan, Md. \&

Areeful Haque

Department of Pharmacy

International Islamic University Chittagong

Chittagong, 4318

Bangladesh

Department of Biochemistry and Molecular Biology

University of Chittagong

Chittagong, 4331

Bangladesh

Md. Adnan

College of Biomedical Science

Department of Bio-Health Technology

Kangwon National University

Chuncheon, 24341

Republic of Korea

Reedwan Bin Zafar Auniq

School of Allied Health Sciences

Walailak University

Nakhon Si Thammarat, 8016

Thailand

Md. Areeful Haque

Drug and Herbal Research Centre

Faculty of Pharmacy

Universiti Kebangsaan Malaysia

50300 Kuala Lumpur, Federal Territory

Malaysia

M. Mosharef Hossain Bhuiyan

Department of Chemistry

University of Chittagong

Chittagong, 4331

Bangladesh

Dina Hajjar, Arwa A. Makki \& Walla Alelwani

Department of Biochemistry

College of Science

University of Jeddah

Jeddah, 80203

Saudi Arabia

*Corresponding author; email: atiar@cu.ac.bd

Received: 10 September 2019

Accepted: 23 March 2020 


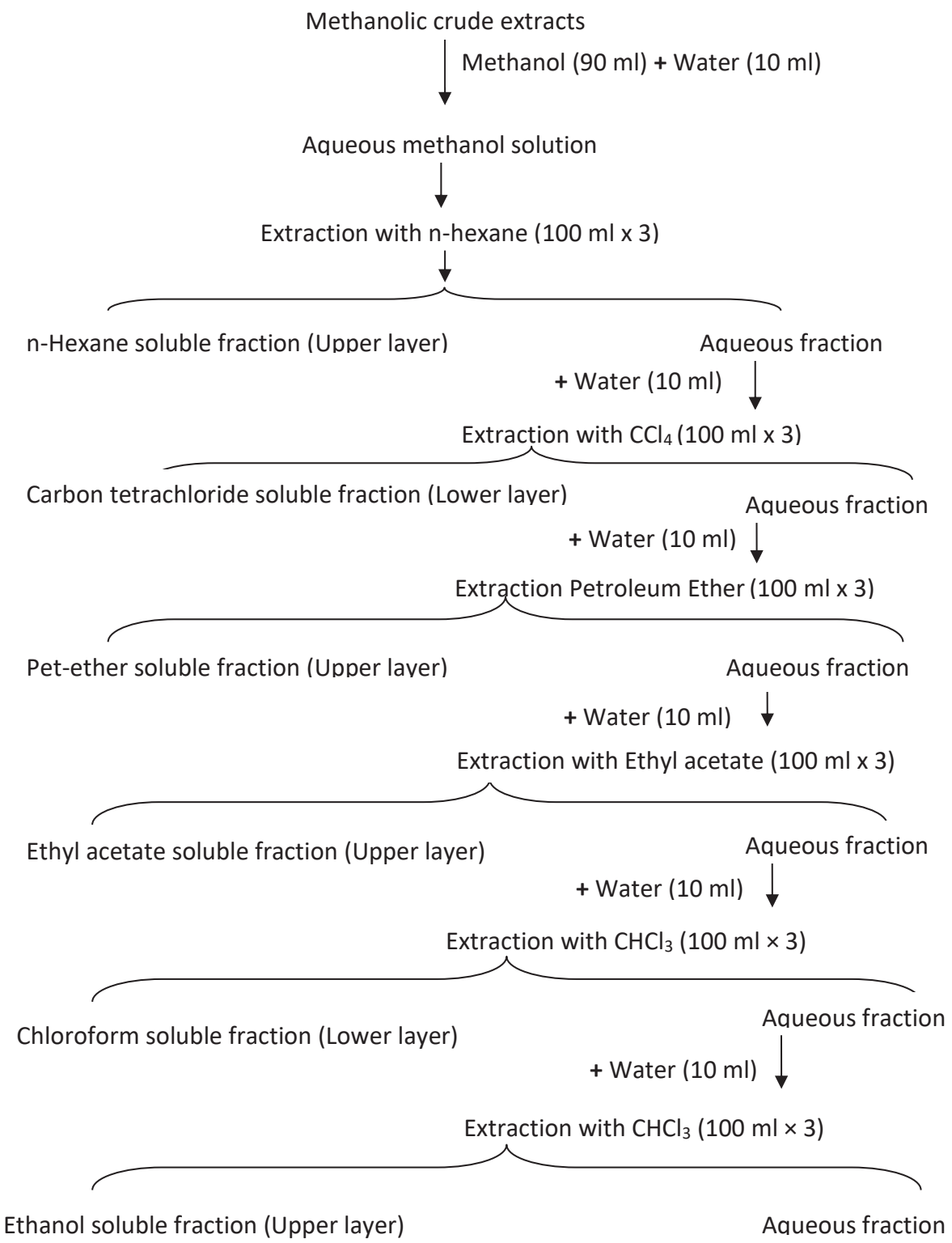

FIGURE 1S. Schematic representation of the modified Kupchan partitioning of methanolic crude extracts of six Asian plants 